\title{
Pengaruh Lama dan Waktu Peneduhan Terhadap Pertumbuhan dan Hasil Kacang Hijau Varietas Camar
}

\author{
DOI 10.18196/pt.2014.018.12-19
}

\author{
Djoko Heru Pamungkas
}

Fakultas Pertanian Universitas Sarjanawiyata Tamansiswa Yogyakarta Jl. Kusumanegara 157 Yogyakarta 55165

e-mail:djoko_herupamungkas@yahoo.com

\begin{abstract}
ABSTRAK
Studi tentang pengaruh peneduhan (tanaman menerima 70\% intensitas sinar matahari penuh) terhadap pertumbuhan dan hasil Camar berbagai kacang hijau dilakukan di Nogotirto, Gamping, Yogyakarta. Percobaan disusun dalam Rancangan Acak Lengkap dengan 3 ulangan. Enam macam perlakuan peneduhan kacang hijau varietas Camar, tanaman menerima 70 persen sinar matahari penuh, yaitu : diteduhi selama siklus hidupnya (A), diteduhi selama setengah pertama siklus hidupnya (B), diteduhi selama setengah kedua siklus hidupnya (C), diteduhi selama seperempat pertama siklus hidupnya (D), diteduhi selama seperempat keempat/terakhir siklus hidupnya (E), dan selama siklus hidupnya tidak diteduhi/kontrol (F). Hasil penelitian menunjukkan bahwa lama dan waktu peneduhan berpengaruh terhadap pertumbuhan dan hasil kacang hijau varietas Camar kecuali terhadap jumlah bintil akar, jumlah bintil akar efektif, umur berbunga tanaman dan berat 100 biji. Hasil biji per hektar pada perlakuan peneduhan selama setengah pertama, seperempat kedua/ terakhir dan selama seluruh siklus hidupnya tidak diteduhi (kontrol), masing-masing tidak berbeda nyata dan berturut-turut adalah 17,71, 17,25, dan 18,20 kuintal. Hasil biji kering tanaman kacang hijau Camar per hektar pada perlakuan peneduhan selama setengah kedua dan seluruh siklus hidupnya, mengalami penurunan masing-masing sebesar 28,95, 32,96, dan 42,36\% dibandingkan kontrol.

Kata kunci : Kacang hijau, Lama peneduhan, Waktu peneduhan
\end{abstract}

\begin{abstract}
A study on the effect of length time shading (approx $70 \%$ of sun rise intensity) to the growth and yield of Camar mung bean variety was conducted in Nogotirto, Gamping, Yogyakarta. The experiment was arranged in a Randomized Complete Block Design with 3 replications. The treatment were 6 levels of length and time of shading of Camar mung bean variety, i.e.: shading at the whole life cycles (A), the first half life cycles (B), the second half life cycles (C), the first quarter life cycles (D), the second quarter life cycles (E) and no shading at the whole life cycles or control (F). The result showed that the length and time of shading affected the growth and yield of Camar mung bean variety significantly except for the number of root - pimples, the number of effective root - pimples and weight of 100 grain per plant parameters. In accordance with the control, the shading at the first quarter and second quarter or at last life cycles gave no significant different in the growth and yield. The yield of that treatments ware 1.77, 1.72 and 1.82 tons seed per hectare. While in accordance with the control, the shading at the first half, the second half and at the whole life cycles gave the lower growth and yields. The decreasing at the yields were 28.95, 32.96 and $42.36 \%$

Key words : Mung bean, Time of shading, Duration of shading
\end{abstract}

\section{PENDAHULUAN}

Asupan gizi yang baik sangatlah diperlukan bagi masyarakat Indonesia untuk meningkatkan kontribusi mereka dalam pembangunan nasional (Suparmoko, 1995). Kacang hijau sebagai salah satu sumber protein nabati, dalam pengembangannya baik melalui ekstensifikasi maupun intensifikasi lebih banyak dilakukan dengan sistem tumpangsari dengan tanaman lain seperti jagung. Hal ini akan menimbulkan masalah yaitu diperoleh hasil lebih rendah akibat tidak terpenuhinya secara tepat baik dalam jumlah maupun lamanya kebutuhan kacang hijau terhadap sinar matahari serta kapan saat yang tepat dalam fase pertumbuhan yang mutlak membutuhkan sinar matahari (Anonim, 1990).

Upaya untuk mendapatkan hasil kacang hijau yang tinggi guna memenuhi kebutuhan sumber protein nabati masyarakat Indonesia yang terus meningkat, perlu dilakukan penelitian untuk 
mengetahui kapan waktu yang tepat selama fase pertumbuhan dan berapa lama tanaman kacang hijau mendapat sinar matahari penuh, sehingga dalam sistem tumpangsari dapat diatur dengan tepat kapan menanam kacang hijau serta kapan pula saat untuk menanam tanaman yang lain seperti jagung dan sebagainya.Peneduhan tanaman kedelai dengan dua taraf intensitas cahaya matahari yaitu $60 \%$ dan $80 \%$ pada saat pembungaan dan pembentukan polong menyebabkan tanaman tumbuh tinggi, pembentukan cabang dan buku berkurang, jumlah biji menurun (Baharsyah, 1980).

Pada sistem tumpangsari, tanaman kedelai yang ditanam dengan jagung akan mengalami penurunan aktivitas fiksasi $\mathrm{N}$ apabila intensitas cahaya matahari yang diterima rendah sehingga mengakibatkan berkurangnya jumlah polong isi. Hasil kedelai akan lebih baik apabila ditanam lebih dahulu dari tanaman naungannya, sebab pada stadium permulaan tumbuh tanaman akan mendapatkan intensitas cahaya matahari cukup tinggi sehingga pertumbuhan vegetatif lebih baik (Oldeman dan Isbagio cit Anonim, 1978). Sementara menurut Anonim (1977), hasil kacang hijau akan menurun apabila ternaungi lebih dari satu minggu setelah tumbuh.

Menurut Fitter dan Hay (1981), masalah yang dihadapi oleh sebuah daun yang ternaungi adalah untuk mempertahankan suatu keseimbangan karbon yang positif dan menurunkan titik kompensasi. Di bawah tekanan cahaya yang rendah, terbuka tiga pilihan yaitu 1) mengurangi kecepatan respirasi untuk menurunkan titik kompensasi, 2) meningkatkan luas daun untuk memperoleh luasan permukaan yang lebih besar bagi absorbsi cahaya, dan 3) meningkatkan kecepatan fotosintesis setiap unit energi cahaya dan luas daun.
Peneduhan tanaman Vicia fabaL. pada berbagai periode pembungaan menunjukkan bahwa peneduhan pada periode pembentukan kuncup bunga mengakibatkan pembentukan kuncup terhambat, sedangkan peneduhan pada periode berbunga penuh menyebabkan jumlah bunga menurun akibat terjadi pengguguran bunga (Smith, 1982 cit Salisbury dan Ross, 1992). Berdasar hal tersebut, penelitian berjudul pengaruh lama dan waktu peneduhan terhadap pertumbuhan dan hasil kacang hijau (Phaseolus radiatusL.) varietas Camar dilakukan dengan tujuan menentukan saat tanam kacang hijau pada sistem tumpangsari yang tepat sehingga peneduhan tidak terjadi pada periode-periode pertumbuhan yang dapat menurunkan hasil. Varietas Camar dipilih karena varietas tersebut sedang disebarluaskan pemerintah karena memiliki kelebihan antara lain tahan bercak coklat (Cercospora Sp.), penyakit kudis (Uromyces), dan tahan pada tanah dengan kadar garam tinggi atau lahan pasang surut, serta hasil rata-rata per hektar cukup tinggi 1,2 ton biji bersih (Anonim, 1991).

Peneduhan (tanaman menerima 70\% intensitas sinar matahari penuh) terhadap kacang hijau pada periode permulaan atau akhir pertumbuhan dengan lama tidak lebih dari seperempat umur diduga dapat memberikan pertumbuhan dan hasil kacang hijau varietas Camar tidak berbeda dengan tanpa peneduhan atau tanaman menerima 100\% intensitas sinar matahari (kontrol).

\section{BAHAN DAN METODE}

Penelitian dilakukan di kebun petani di Desa Nogotirto, Kecamatan Gamping, Kabupaten Sleman, Propinsi DIY dengan jenis tanah Regosol. Bahan-bahan yang digunakan dalam penelitian antara lain: benih kacang hijau 
varietas Camar berasal dari Dinas Pertanian

Guning Kidul, pupuk Urea, TSP dan $\mathrm{KCl}$ serta insektisida Durban.

Alat yang dipersiapkan antara lain : alat peneduh terbuat dari anyaman daun kelapa dengan kemampuan meneruskan sinar matahari lebih kurang 70 persen, lightmeter, leafareameter, cangkul, tugal, sprayer, timbangan, penggaris, tanda perlakuan dari karton, dan alat tulis.

Penelitian menggunakan Rancangan Acak Kelompok Lengkap dengan tiga ulangan. Percobaan yang dilakukan terdiri enam macam perlakuan peneduhan kacang hijau varietas Camar, tanaman menerima 70 persen sinar matahari penuh, yaitu : diteduhi selama siklus hidupnya (A), diteduhi selama setengah pertama siklus hidupnya (B), diteduhi selama setengah kedua siklus hidupnya (C), diteduhi selama seperempat pertama siklus hidupnya (D), diteduhi selama seperempat keempat/terakhir siklus hidupnya (E), dan selama siklus hidupnya tidak diteduhi/kontrol (F). Petak percobaan berukuran 2,4 m x 1,8 m. Jarak antar blok 0,75 $\mathrm{m}$, jarak antar petak $0,75 \mathrm{~m}$. Pemasangan alat peneduh dilakukan dengan meletakkan anyaman daun kelapa pada empat tiang pancang dari bambu di luar bedengan sedemikian rupa sehingga sinar matahari yang diterima tanaman sesuai perlakuan. Apabila telah cukup waktu, alat peneduh diambil atau diturunkan.

Pengontrolan $70 \%$ intensitas sinar matahari yang diterima tanaman selama peneduhan setiap minggu sekali dicek dengan lightmeter yaitu dengan mengukur intensitas sinar matahari di atas naungan $100 \%$, sedangkan di bawah naungan diupayakan besarnya 70\% dengan memperlebar jarak anyaman daun kelapa.
Penanaman benih dilakukan pada kedalamam $3 \mathrm{~cm}$. Jarak tanam 30x20 cm sesuai rekomendasi Dinas Pertanian, setiap petak percobaan terdapat 55 lubang tanam. Setiap lubang tanam 4 benih. Setelah tumbuh dan berumur satu minggu disisakan 1 tanaman saja.

Pemberian pupuk urea, TSP dan KCIper petak, masing-masing sebanyak 10,8g (25 kg per hektar) dilakukan pada saat tanam dengan cara mencampur ketiga pupuk tersebut dan selanjutnya disebar dalam larikan-larikan di sekitar lubang tanam.

Pemberian air dilakukan dengan sistem siraman menggunakan gembor secara hati-hati sampai tanaman basah secara merata dan tanah dalam keadaan kapasitas lapang. Frekuensi pemberian air 5 hari sekali. Penyiangan gulma dilakukan setiap waktu secara mekanis saat terlihat gulma yang tumbuh di petak-petak percobaan. Pengendalian hama lalat kacang dilakukan menggunakan insektisida Dursban 20 EC konsentrasi $3 \mathrm{ml} / 1$ air, dengan cara disemprotkan merata ke semua bagian tanaman terutama yang mengalami serangan serius.

Pemanenan dilakukan 5 kali, dimulai pada umur 60 hari saat polong sudah berwarna hitam dan kering, tekstur polong kerasserta warna daun tanaman hijau kekuningan. Panen berikutnya dilakukan setiap 3 hari.

Tanaman sampel terdiri dari 5 tanaman dalam petak percobaan yang dipilih secara acak. Pengamatan tanaman sampel dilakukan pada parameter pertumbuhan, yaitu tinggi tanaman, jumlah buku, jumlah buku subur, jumlah bintil akar, jumlah bintil akar efektif, umur berbunga tanaman, berat segar, berat kering tanaman. Komponen hasil meliputi : jumlah polong, jumlah biji per tanaman. Juga terhadap analisis tumbuh, yaitu laju asimilasi bersih pada fase vegetatif dan generatif. Pengamatan petak 
sampel meliputi hasil biji dan berat 100 biji. Selanjutnya hasil per petak dikonversikan ke hasil biji per hektar.

Data yang terkumpul dianalisis denga nanalisis sidik ragam pada tingkat kesalahan 5 persen. Hasil analisis yang menunjukkan beda nyata diuji lebih lanjut dengan uji jarak berganda Duncan (Duncan's Multiple Range Test) pada tingkat kesalahan 5 persen.

\section{HASIL DAN PEMBAHASAN}

\section{Pertumbuhan Tanaman}

Data pada tabel 1 menunjukkan bahwa peneduhan selama seperempat pertama dan terakhir siklus hidup tanaman kacang hijau varietas Camar menghasilkan tinggi tanaman, jumlah buku total maupun buku subur tidak berbeda dibandingkan dengan tanaman tanpa peneduhan selama siklus hidupnya (kontrol). Namun ketiga perlakuan nyata lebih tinggi dibandingkan dengan tanaman yang mendapat peneduhan selama setengah pertama, setengah kedua dan seluruh siklus hidupnya.

Pada peneduhan selama setengah pertama dan seluruh siklus hidupnya, masing-masing tanaman akan berusaha menaikkan tinggi tajuknya dan mencapai matahari penuh sekaligus menghemat energi dengan tidak membentuk cabang terlalu banyak serta mengurangi jumlah buku. Namun pada tanaman yang mendapat peneduhan selama seperempat pertama dan seperempat terakhir siklus hidupnya, keadaan demikian tidak terjadi oleh sebab tanaman dapat menerima intensitas sinar matahari cukup sehingga asimilat yang dibentuk cukup untuk membentuk percabangan, buku dan jumlah buku yang dapat menghasilkan polong serta biji yang lebih banyak.
Tabel 1 Rerata Tinggi Tanaman, Jumlah Buku, Jumlah Buku Subur, Jumlah Bintil Akar Jumlah Bintil Akar Efektif, Berat Segar dan Berat Kering Tanaman Kacang Hijau Varetas Camar Dengan Perlakuan Lama dan Waktu Peneduhan

\begin{tabular}{|c|c|c|c|c|c|c|}
\hline \multirow{2}{*}{ PARAMETER } & \multicolumn{6}{|c|}{ PERLAKUAN } \\
\hline & A & B & $C$ & $D$ & $E$ & $F$ \\
\hline Tinggi Tanaman (cm) & $57,1 \mathrm{~b}$ & $56,4 b$ & $55,1 \mathrm{~b}$ & $45,0 a$ & $46,3 a$ & $44,3 a$ \\
\hline Jumlah Buku & $10,3 a$ & $10,3 a$ & $11,6 \mathrm{~b}$ & $11,9 \mathrm{~b}$ & $11,9 \mathrm{~b}$ & $12,0 \mathrm{~b}$ \\
\hline Jumlah Buku Subur & 9,4 a & $9,3 a$ & $9,5 a$ & $10,9 \mathrm{~b}$ & $10,6 b$ & $11,1 b$ \\
\hline Jumlah Bintil Akar & $11,2 a$ & $11,5 a$ & $11,4 a$ & $11,6 a$ & $11,9 a$ & $12 a$ \\
\hline Jumlah Bintil Akar Efektif & $11,0 a$ & $11,3 a$ & $11,2 a$ & $11,8 a$ & $11,8 a$ & $11,9 a$ \\
\hline Berat Segar Tanaman (g) & $10,2 a$ & $10,3 a$ & $10,4 a$ & $12,9 \mathrm{~b}$ & $13, \mathrm{lb}$ & $13,4 b$ \\
\hline Berat Kering Tanaman (g) & $8,2 a$ & $8,6 a$ & $8,5 a$ & $10,4 b$ & $10,7 \mathrm{~b}$ & $10,9 \mathrm{~b}$ \\
\hline
\end{tabular}

Jumlah Bintil Akar dan Jumlah Bintil Akar Efektif

Jumlah bintil akar dan jumlah bintil akar efektif per tanaman yang mendapat peneduhan (sebagian maupun seluruh siklus hidupnya) tidak berbeda dibandingkan dengan tanpa peneduhan (kontrol) (Tabel 1). Pembentukan bintil akar tampaknya tidak dipengaruhi secara langsung oleh penerimaan cahaya tanaman, akan tetapi lebih ditentukan oleh tersedianya unsur hara nitrogen $(\mathrm{N})$ dan fosfor $(\mathrm{P})$. Hal ini sesuai pendapat Anonim (1991) bahwa unsur P berperanan dalam pembentukan bintil akar, bunga, dan buah. Sementara menurut Sarief (1989), jika tersedia P dalam tanah dan tanaman tercukupi maka dapat merangsang pertumbuhan akar berikut bintil akarnya dan apabila pembentukan bintil akar berjalan baik, maka fiksasi $\mathrm{N}_{2}$ udara juga baik. 


\section{UmurBerbunga Tanaman}

Perlakuan lama dan waktu peneduhan tidak berpengaruh nyata terhadap umur berbunga tanaman (Tabel 2). Hal ini menunjukkan bahwa tanaman kacang hijau termasuk tumbuhan hari netral yang tidak responsif terhadap panjang hari untuk pembungaannya. Tingkat intensitas cahaya berpengaruh terhadap perkembangan bunga tetapi tidak mempengaruhi umur (saat) berbunga tanaman.

\section{Berat 100 Biji per Tanaman}

Perlakuan lama dan waktu peneduhan tidak berbeda nyata terhadap berat 100 biji per tanaman (Tabel 2). Ukuran biji maksimal sangat ditentukan oleh sifat genetik. Pembentukan dan pengisian biji sangat ditentukan oleh asimilat yang dibentuk saat fase vegetatif (cadangan yang disimpan dalam tubuh tanaman) dan selama fase generatif (fase pembentukan dan pengisian polong) (Pantastico, 1986). Keadaan demikian berakibat pengaruh lama dan waktu peneduhan berbeda terhadap jumlah polong dan biji yang terbentuk tetapi pengaruhnya tidak berbeda terhadap setiap ukuran biji maksimal yang dihasilkan.

Intensitas sinar matahari penuh dan lama penerimaan sinar matahari penuh yang cukup pada fase awal pertumbuhan maupun fase pengisian polong tanaman kacang hijau dengan perlakuan peneduhan selama seperempat pertama maupun terakhir siklus hidupnya, mengakibatkan laju asimilasi bersih selama fase vegetatif maupun generatif berjalan normal dan asimilat yang dihasilkan selama kedua fase pertumbuhan tersebut dapat dipergunakan untuk pembentukan organ tanaman yang berperanan bagi pembentukan asimilat maupun organ reproduksi seperti polong dan biji pada setiap tanaman, sehingga memberikan hasil biji per tanaman maupun per hektar tinggi dan tidak berbeda dibandingkan dengan perlakuan tanpa peneduhan selama siklus hidupnya (kontrol pada tabel 2). Menurut Harjadi (1979), umumnya hasil setiap satuan luas yang tinggi karena tercapainya penggunaan cahaya secara maksimal di awal pertumbuhan.

Tabel 2 Rerata Umur Berbunga, Jumlah Polong, Jumlah Biji Per Tanaman, Berat 100 Biji dan Hasil Biji Per Hektar Tanaman Kacang Hijau Varietas Camar Dengan Perlakuan Lama dan Waktu Peneduhan

\begin{tabular}{|c|c|c|c|c|c|c|}
\hline \multirow{2}{*}{ PARAMETER } & \multicolumn{6}{|c|}{ PERLAKUAN } \\
\hline & A & $B$ & C & $D$ & $E$ & $\mathrm{~F}$ \\
\hline Umur berbunga tanaman (hr) & $32,0 a$ & $30,6 a$ & $31,3 a$ & $29,0 a$ & $29,3 a$ & $28,7 a$ \\
\hline Jumlah polong per tanaman & $13,0 a$ & $15,7 a$ & $14,7 a$ & $24,6 b$ & $22,3 b$ & $24,6 b$ \\
\hline Jumlah biii per tanaman & $50,3 a$ & $52,7 a$ & $56,3 a$ & $88,6 \mathrm{~b}$ & $89,3 b$ & $99,0 \mathrm{~b}$ \\
\hline Berat 100 biii (g) & $7,6 a$ & $7,6 a$ & 7,4 a & $7,5 a$ & $7,6 a$ & $7,6 a$ \\
\hline Hasil biii per hektar (ku) & $11,5 a$ & $12,9 a$ & $12,2 a$ & $17,7 \mathrm{~b}$ & $17,2 b$ & $16,2 b$ \\
\hline
\end{tabular}

Keterangan : Angka rerata yang diikuti huruf sama pada setiap baris yang sama menunjukkan tidak ada beda nyata pada taraf $5 \%$ berdasarkan Uji Jarak Berganda Duncan.

\section{Jumlah Polong Per Tanaman, Jumlah Biji Per} Tanaman dan Hasil Biji Per Hektar

Hasil biji per hektar pada perlakuan peneduhan selama setengah pertama siklus hidupnya yang lebih rendah dibandingkan kontrol, disebabkan rendahnya asimilat yang dibentuk pada fase pertumbuhan vegetatif (LAB umur 30-38 hari lebih rendah dibanding kontrol) oleh sebab tersedianya kuantitas sinar matahari yang rendah, selanjutnya menjadi meningkatnya asimilat yang dihasilkan selama fase generatif (LAB pada fase generatif tetap lebih rendah dibandingkan kontrol) meskipun dapat mendukung perkembangan organ reproduksi yang dibentuk (dengan jumlah lebih rendah) akan tetapi hasil biji kering tetap lebih rendah dibandingkan dengan kontrol.

Lebihrendahnya hasil biji per hektar kacang hijau pada perlakuan peneduhan setengah 
kedua siklus hidupnya dibandingkan kontrol, karena pertumbuhan awal (fase vegetatif) yang terdukung oleh intensitas sinar matahari penuh sehingga asimilat yang dihasilkan pada fase tersebut juga normal (LAB fase vegetatif tidak berbeda dibandingkan kontrol), namun selanjutnya memasuki fase generatif ada penurunan intensitas sinar matahari penuh (adanya peneduhan) sehingga asimilat yang dihasilkan menurun pula (LAB fase generatif lebih rendah dibanding kontrol). Hal tersebut menyebabkan selama pembentukan polong dan pengisian polong (pembentukan biji) kebutuhan asimilat tidak terpenuhi yang mengakibatkan hasil per tanaman rendah. Keterkaitan bagian vegetatif dengan hasil (bagian reproduksi) dijelaskan oleh Gardner et al. (1991) bahwa akibat dari mobilisasi hasil asimilasi dan nutrisi mineral dari bagian vegetatif ketempat pembentukan buah dan biji selama fase generatif menyebabkan buah dapatterus berkembang. Pada tahap pra antesis (pertumbuhan ovarium), perkembangan buah terutama disebabkan oleh perbanyakan sel, sedangkan pada tahap pasca fertilisasi ukuran buah meningkat terutama karena pembesaran sel.

\section{BeratSegar dan Berat Kering Tanaman}

Peneduhan (tanaman menerima 70 persen intensitas cahaya matahari penuh) selama setengah pertama, setengah kedua dan seluruh siklus hidupnya menyebabkan penerimaan tanaman terhadap intensitas cahaya matahari menurun sehingga menurunkan laju asimilasi bersih secara keseluruhan (LAB fase vegetatif maupun generatif yang dapat dilihat pada tabel 3) dan berakibat terhambatnya pertumbuhan organ tanaman (memberikan berat segar dan kering tanaman lebih rendah dibandingkan dengan perlakuan peneduhan selama seperempat pertama, seperempat keempat/ terakhir dan selama seluruh siklus hidupnya mendapat sinar matahari penuh (intensitas sinar matahari 100 persen). Hal ini sesuai pendapat Gardner et al (1991), bahwa berat kering tanaman merupakan efisiensi penyerapan dan pemanfaatan radiasi matahari yang tersedia sepanjang musim pertumbuhan oleh tajuk tanaman. Efisiensi penyerapan dan pemanfaatan radiasi matahari ini sangat berkaitan erat dengan proses fotosintesis, karena komponen utama proses fotosintesis adalah radiasi matahari. Jika jumlah daun yang dapat melakukan kegiatan fotosintesis banyak, akan meningkatkan hasil fotosintesis, sementara William dan Joseph (1976) menyatakan bahwa intensitas sinar matahari rendah akan menurunkan fotosintesis dan menghambat pertumbuhan organ tanaman.

Pada perlakuan peneduhan selama seperempat pertama siklus hidupnya maupun seperempat keempat/terakhir siklus hidupnya, penerimaan intensitas sinar matahari yang tidak penuh tidak lebih dari dua minggu setelah tumbuh maupun pada akhir fase pengisian polong (fase generatif) mengakibatkan laju asimilasi bersih keseluruhan (selama fase vegetatif maupun generatif) tetap tinggi sehingga pertumbuhan vegetatif tidak terhambat. Hal ini sesuai dengan pendapat Oldman dan Isbagio cit Anonim (1978) bahwa apabila pada stadia permulaan tumbuh tanaman mendapat intensitas sinar matahari cukup tinggi, pertumbuhan vegetatif akan lebih baik.

Penerimaan intensitas sinar matahari penuh pada awal pertumbuhan selama sebagian (tidak lebih dari dua mmggu pada perlakuan peneduhan selama seperempat pertama siklus hidupnya) dan seluruh fase pertumbuhan 
Tabel 3. Rerata Laju Asimilasi Bersih (LAB) Tanaman Kacang Hijau Varietas Camar pada Fase Vegetatif dan Generatif dengan Perlakuan Lama dan Waktu Peneduhan.

\begin{tabular}{llllllll}
\hline \multirow{2}{*}{ PARAMETER } & \multicolumn{1}{c}{ PERLAKUAN } & & & & \\
\cline { 2 - 7 } & $\mathrm{A}$ & $\mathrm{B}$ & $\mathrm{C}$ & $\mathrm{D}$ & $\mathrm{E}$ & $\mathrm{F}$ \\
\hline LAB pada umur 30-38 hari (g/dm luas daun/hari) & $0,042 \mathrm{a}$ & $0,043 \mathrm{a}$ & $0,093 \mathrm{~b}$ & $0,092 \mathrm{~b}$ & $0,111 \mathrm{~b}$ & $0,125 \mathrm{a}$ \\
LAB pada umur 46-54 hari (g/dm luas daun/hari) & $0,048 \mathrm{a}$ & $0,102 \mathrm{a}$ & $0,053 \mathrm{a}$ & $0,136 \mathrm{~b}$ & $0,139 \mathrm{~b}$ & $0,143 \mathrm{~b}$ \\
\hline
\end{tabular}

Keterangan : Angka rerata yang diikuti huruf sama pada setiap baris yang sama menunjukkan tidak ada beda nyata pada taraf $5 \%$ berdasarkan Uji Jarak Berganda Duncan.

vegetatif (pada perlakuan peneduhan selama setengah kedua siklus hidupnya) dapat mendukung laju asimilasi bersih fase pertumbuhan vegetatif berjalan lancar sehingga masing-masing tidak berbeda dibandingkan dengan kontrol (tabel 3). Tanaman yang menerima peneduhan selama setengah pertama siklus hidupnya (70 persen intensitas sinar matahari yang diterima selama fase pertumbuhan vegetatif) menyebabkan rendahnya LAB (Laju Asimilsi Bersih) selama fase vegetatif. Penurunan intensitassinar matahari yang diterima selama fase generatif pada tanaman yang mendapat peneduhan selama setengah kedua siklus hidupnya menyebabkan lebih rendahnya LAB pada fase generatif dibandingkan kontrol. Sebaliknya, untuk tanaman yang memperoleh sinar matahari penuh selama setengah kedua siklus hidupnya (perlakuan peneduhan selama setengah pertama siklus hidupnya) menunjukkan LAB pada fase generatif tinggi sehingga tidak berbeda dibandingkan kontrol (tabel 3). Hal ini sesuai pendapat Harjadi (1979), bahwa sinar matahari merupakan energi pada proses fotosintesis, oleh karenanya intensitas, kualitas dan lamanya penyinaran berpengaruh pada proses tersebut. Sementara Williams dan Joseph (1976) menyatakan bahwa intensitas sinar matahari rendah akan menurunkan hasil bersih fotosintesis dan menghambat pertumbuhan organ tanaman.

\section{SIMPULAN}

Dari basil penelitian ini, maka dapat disimpulkan sebagai berikut :

a. Perlakuan peneduhan terhadap tanaman kacang hijau varietas Camar, kecuali terhadap jumlah bintil akar, jumlah bintil akar efektif, umur berbunga tanaman dan berat 100 biji, masing-masing pengaruhnya berbeda nyata terhadap komponen pertumbuhan, komponen hasil, hasil dan analisis tumbuh.

b. Perlakuan peneduhan (tanaman menerima 70 persen intensitas sinar matahari penuh) selama seperempat pertama dan seperempat terakhir siklus hidupnya, kecuali terhadap jumlah bintil akar, jumlah bintil akar efektif, umur berbunga, dan berat 100 biji, masingmasing memberikan komponen pertumbuhan, komponen hasil dan hasil biji per hektar, dan analisis tumbuh tidak berbeda nyata dibandingkan dengan kontrol (selama seluruh siklus hidupnya tidak diteduhi), namun kedua perlakuan tersebut nyata lebih tinggi dibandingkan dengan 
perlakuan peneduhan selama setengah pertama, setengah kedua, dan seluruh siklus hidupnya. Sedangkan perlakuan peneduhan selama setengah pertama, setengah kedua dan seluruh siklus hidupnya, masing-masing tidak berbeda nyata, namun ketiganya lebih rendah dibandingkan kontrol.

c. Hasil biji kering tanaman kacang hijau Camar per hektar pada perlakuan peneduhan selama setengah kedua dan seluruh siklus hidupnya, masing-masing adalah 12,93, 12,20, dan 10,49 kuintal, yang berarti masing-masing terjadi penurunan 28,95, 32,96, dan 42,36\% dibandingkan kontrol. Hasil biji per hektar pada perlakuan peneduhan selama setengah pertama, seperempat kedua/terakhir dan selama seluruh siklus hidupnya tidak diteduhi (kontrol), masing-masing tidak berbeda nyata dan berturut-turut adalah 17,71, 17,25, dan 18,20 kuintal.

Dari penelitian ini ada saran antara lain:

a. Pengaturan penanaman kacang hijau varietas Camar dalam sistem tumpangsari sebaiknya dilakukan tidak lebih dua minggu sebelum panen tanaman lainnya ataupun penanaman tanaman lainnya dilakukan tidak lebih dua minggu sebelum panen tanaman kacang hijau.

b. Kacang hijau varietas Camar baik digunakan di lahan jenis Regosol dengan pemupukan $\mathrm{KCl}$, TSP, dn Urea cukup.

\section{DAFTAR PUSTAKA}

, 1977. The Philipines Recommend For Mungo. AVRDC. Los Banos. Laguna. $62 \mathrm{p}$.

--_-, 1978. Peranan Iklim Pada Pola Tanam Tumpanggilir. Dalam Lokakarya Pola Tanam Tumpanggilir. Kumpulan Makalah Cipanas. 289 hal.

_-_- 1990. Usaha IntensifikasiBertanam Kacang Hijau. Dinas Pertanian Tanaman Pangan Propinsi DIY. 18 hal.
1991. Varietas Barn Kacang Kedelai dan Kacang Hijau Hasil Radiasi. dalam Harian Kompas. No. 275. Tahun ke 26. PT. Gramedia. Jakarta.

Baharsyah, S. 1980. Pengaruh Intensitas Cahaya Terhadap Pertumbuhan, Hasil, dan Komponen Hasil Kedelai (Glycine maxL. (Merr)). Buletin Penelitian IPB. I: 77

Fitter, A.H. dan R.K.M. Hay. 1981. Enviromental Physiology of Plants. Terjemahan Andani, S dan E.D. Purbayanti. 1991. Fisiologi Lingkungan Tanaman. Gadjah Mada University Press. 421 hal.

Gardner, FP., RB Pearce, dan R.L Mitchell. 1991. Physiologi of Crop Plant Terjemahan. Susilo, H. 1991. Fisiologi Tanaman Budidaya. UI Press. Jakarta. 428 hal.

Harjadi, S.S. 1979. Pengantar Agronomi. PT. Gramedia. Jakarta 195 hal.

Pantastico, ER. 1986. Fisiologi Pasca Panen. Terjemahan. Kamarjani. Gadjah Mada Univercity Press. Yogyakarta. 906 hal.

Sarief, E.S. 1986. IImu Tanah Pertanian. Pustaka Buanan. Bandung. 156 hal.

Salisburry, F.B. dan Cleon W. Ross. 1992. Plant Physiology, $4^{\text {th }}$ edition. Terjemahan Lukman, D.R dan Sumaryono. 1992. Fisiologi Tumbuhan. Penerbit ITB. Bandung. 343 hal.

Smith, M.L. 1982. The Effect of Shading at Different Periode During Flowering on Flower Abscission in Vicia fabal. minor. Field Crop Abstract. 36 (4) : 102.

Williams, C.N dan K.T. Joseph. 1976. Plant Physiology. D.Van Norstrand Company. Canada. 398 p. 